\title{
Hydrology-Shaped Plant Communities: Diversity and Ecological Function
}

\author{
Alenka Gaberščik and Igor Zelnik *(1) \\ Department of Biology, Biotechnical Faculty, University of Ljubljana, Jamnikarjeva 101, 1000 Ljubljana, Slovenia; \\ alenka.gaberscik@bf.uni-lj.si \\ * Correspondence: igor.zelnik@bf.uni-lj.si
}

check for updates

Citation: Gaberščik, A.; Zelnik, I.

Hydrology-Shaped Plant

Communities: Diversity and

Ecological Function. Water 2021, 13,

3525. https://doi.org/10.3390/

w13243525

Received: 23 November 2021

Accepted: 7 December 2021

Published: 9 December 2021

Publisher's Note: MDPI stays neutral with regard to jurisdictional claims in published maps and institutional affiliations.

Copyright: (c) 2021 by the authors. Licensee MDPI, Basel, Switzerland. This article is an open access article distributed under the terms and conditions of the Creative Commons Attribution (CC BY) license (https:// creativecommons.org/licenses/by/ $4.0 /)$.

\section{Introduction}

Water is not only the essence of life and medium of organisms but also the environmental factor that shapes biocenoses, including plant communities. These communities are affected by the availability of water for single plant species or by hydrological regimes that may cause disturbance by physical force or stress due to high water levels and droughts. In many ecosystems, the hydrological regime presents major determinant that affects plant species composition, succession, productivity, and stability of plant communities. The hydrological regime is characterized by changes in the levels and volumes of water in rivers, lakes, reservoirs, and wetlands in time and space as well as by the currents and waves. According to Keddy [1], wetlands comprise a variety of ecosystems marked by permanent or temporal presence of water above the ground, namely floodplain forests and mangals, marshes with prevailing helophytes rooted in waterlogged soils, bogs dominated by peat mosses overgrowing thick layer of peat, fens with prevailing sedges and grasses and shallow peat layer, wet meadows dominated by herbaceous plants on occasionally flooded soils, and shallow water bodies colonized by truly aquatic plants. The structure of specific wetland depends on the climate, landscape morphology, and hydrological regime. The following aspects of a hydrological regime may affect diversity and functioning of plant communities: the presence of water in time (permanent, seasonal, and occasional), the frequency and the duration of flooding, the volume and depth of water, the variability in changes over time, and the predictability of a water regime [2]. The functional traits of plant species colonizing different wetlands or water bodies are adjusted to specific hydrological regimes and define community characteristics and their colonization and competition potential.

This Special Issue includes a variety of papers reporting about long-term researches of ecosystems where the hydrological regime presents an important factor in shaping plant communities, such as lake, intermittent lake, kettle-holes, lagoon, rivers, floodplain forests, and wet meadows. To show these effects of a hydrological regime along with other environmental factors, some authors concentrated on single species, on a group of plants, or on plant communities. The studied plant species range from fragile stonewort to giant oak-tree, but most of the authors focused on herbaceous vascular plants. Most of these ecosystems were studied from their banks or by wading in their shallow parts, but some of them were monitored by boat or even from the air.

Beside the widening specific knowledge on the certain ecosystem, especially the knowledge on interactions between plant communities and hydrological regime, some contributions published in this book may have important implications from the viewpoint of global warming and climate changes that affect the amount and distribution of precipitation and thus the hydrological regimes of many ecosystems. Aquatic ecosystems monitored for several years or even long-term studies provide valuable results of the changes with time, which we urgently need for more reliable forecasts of future trends. 


\section{Main Messages of This Special Issue}

The study of Šumberová et al. [3] investigated the diversity of vascular plants, charophytes, and diatoms in relation to a range of environmental factors in a large hypertrophic fishpond in order to point out the main drivers affecting these communities and to improve the understanding and the basis for protection of threatened aquatic ecosystems. The advantage of this study is that the authors summarized the results of several growing seasons. Even though the life histories of the studied groups differ significantly, the outcomes show that they responded in the same way to specific locally important environmental factors, such as water depth and transparency, water level fluctuations, nutrient contents, sediment type, littoral morphology, and disturbance intensity. A complex data analysis revealed that, due to the synergistic effects of a hydrological regime, climatic conditions, and management measures, the overall conditions in the littoral zone of a fishpond were similar such as in temporary wetlands. Due to the wide range of tested variables and extreme climatic conditions during the experimental period, this study presents a basis for the prediction of directions of community changes in hypertrophic water bodies under ongoing climate change.

Cyperus fuscus is a plant species that colonizes wet areas, especially disturbed places such as temporary ponds and ditches. The paper by Kúr et al. [4] discussed the ecology and genetics of $C$. fuscus, which serves as a model for ephemeral wetland plant research and their conservation. The author presumed that plant community diversity may exert a direct effect on within-population genetic diversity, which may vary in different species regarding their competitive ability. The study showed that $C$. fuscus thrives in a broad range of vegetation types, with an optimal distribution in the communities of the IsoëtoNanojuncetea class. As a thermophilous species, it is expected to spread to previously cooler habitats due to climate change. This possibly holds true also for the great share of co-habitating thermophilous species. Even though C. fuscus was considered basiphilous species, it seems to be a generalist regarding soil reaction since it was found at locations with lower calcium availability. Another important result of this paper is that the relevés with C. fuscus included relatively high number of alien species, but no negative effect on $C$. fuscus cover was detected. The relationship between vegetation diversity in natural habitats and genetic diversity is slightly negative, while anthropogenically modified habitats exerted a strong negative effect on the genetic diversity of this species. These outcomes have important implications for conservation, since only the preservation of natural habitats ensures the maintenance of the adaptive potential of the species.

The territory of Slovenia is geomorphologically, geologically, climatically, and edaphically very diverse and belongs to different ecoregions. This diversity reflects the high biotic diversity of terrestrial ecosystems [5]; however, the diversity in aquatic systems is known to the lesser extent. Zelnik et al. [6] studied vascular plant communities in 33 watercourses in different regions of Slovenia. Hydrologically, the most outstanding is the Karst region, where watercourses are marked by extreme water level fluctuations and even intermittence, which affect the presence of vascular plants. The overall analysis showed that species presence and abundance were at most affected by the longitudinal characteristics of the rivers. The species that were the most abundant in these watercourses have wide ecological ranges. The authors determined 87 vascular plant taxa in total and distinguished 25 different plant associations belonging to 5 classes and 9 alliances. The study showed that the majority of plant communities were distributed in different watercourses belonging to different hydro-ecoregions. Only seven communities showed narrow distribution ranges, and three of them were recorded in karst poljes, including the new association between Mentho aquaticae and Oenanthetum fistulosae from the karst river Mali Obrh. This distribution pattern reveals specific environmental conditions in these karst poljes and a lack of regionality elsewhere, even though this regionality is evident in the case of terrestrial ecosystems [5].

The Danube River is the second-longest river in Europe that is subjected to various human-made alterations, including those related to hydro-power plants. The extensive 
study of Janauer et al. [7] is a unique compilation of knowledge on macrophyte species, aquatic plant communities, and their habitat preferences in the Danube main channel from 2582 river kilometers $(\mathrm{rkm})$ to $171 \mathrm{rkm}$. The authors recorded 89 different aquatic macrophyte species along the entire course-among them, neophytes Elodea nuttallii, E. canadensis, Vallisneria spiralis, and Azolla filiculoides-and distinguished 15 plant communities, which were classified into five alliances and represented vegetation classes-namely, rooted hydrophytes Potamogetonetea, pleustophytes Lemnetea, and helophytes Phragmitetea. The Danube is far from being a natural river, but some free-running sections have reasonably low human interference. The study revealed that the distribution of macrophyte species and their communities reflect neither the river continuum concept [8] nor a specific regionality [9]. The present study revealed that hydrological regime significantly affected species presence and abundance, since impounded sections of the river were richer in number and abundance of plant species, whereas the free-running sections mainly show the opposite result. Based on the distribution of aquatic macrophytes and communities, four different sections of the river can be distinguished. The main reason for this distribution pattern is human activity generating disturbances (e.g., navigation, hydropower-plants, and pollution). This study not only is a summary of the present knowledge on macrophyte and their communities in the Danube River but also presents a baseline for determining future changes of the aquatic vegetation.

Kettle holes are glacially shaped small lentic waterbodies characterized by a wetdry-cycle that supports high species diversity. Due to eutrophication, they are a source of greenhouse gasses; thus, effective conservation and management strategies should be established. Pätzig and Düker [10] used manually digitized maps derived by unmanned aerial systems to quantify differences among dominant plant communities of kettle holes between 2015 and 2020, when several extreme weather events took place in order to contribute to the understanding of functions and services of these specific ecosystems. A high variability in an open water area in these kettle holes in 2016, 2018, and 2020 caused a shift in the occurrence and dominance of plant communities. Various dominant plant communities were differently affected by dry and wet intervals with a major increase in terrestrial plants. High correlation with decreased water permanence was observed for nitrophilous perennials and woody plants. Communities with dominant taxa Carex spp., Phragmites australis, and Phalaris arundinacea revealed no significant changes over the entire period, since they colonize kettle holes with different characteristics. The authors claimed that they expected a lower precipitation rate due to climate changes preventing the reset of early succession stages; thus, the succession of woody species will be accelerated under drier conditions, especially in the absence of management. This results in increased homogenization of the landscape, and loss of certain ecosystem functions and services.

Floodplain forests are complex ecosystems that colonize natural levees, low ridges, bottoms, sloughs, and back-swamps of rivers. In the past, they were cleared due to agriculture, dam impoundments, farming, and urbanization and reduced to narrow bands along the rivers. Hardwood floodplain forests serve as natural carbon sinks; therefore, the reforestation of floodplains may increase their carbon storage potential. Shupe et al. [11] studied carbon stocks in floodplain forests of different ages, structures, and hydrological conditions. Trees in these forests are adapted to cope with large water level fluctuations that may result in hypoxic or anoxic conditions during flooding and water shortage during the dry period. Authors report that the carbon stock accumulated in young trees is significantly lower than in trees of old dense or sparse forests. Old forests thriving on low active floodplains, the high active floodplain, the seepage water zone, and tributaries have the same level of carbon storage; therefore, such locations seem suitable for reforestation process. The comparison of different species revealed that Quercus robur accumulated much more carbon than any other species in all hydrological conditions, while other species accumulated much less carbon, and their potential varied among different habitats.

Wet meadows are wetlands with specific hydrological conditions. They develop on poorly drained areas such as shallow lake basins and on land in the transition be- 
tween marshes and upland areas. Wet meadows are usually without standing water, with exception to the periods of seasonal high waters when they are inundated or waterlogged. These specific conditions and fertile soil create favorable habitats for a variety of plant communities. Inappropriate hydrological interventions or management practices may endanger these communities. The contribution of Čarni et al. [12] discussed wet meadow plant communities of the alliance Trifolion pallidi that colonize riverside terraces or gentle slopes along watercourses in the southeastern part of the Pannonian Plain. The hydrological gradient along with nutrient availability is a key factor that determines the growth of different species, as shown by Ellenberg indicator values. The Extent database enabled the distinction of four plant associations: Trifolio pallidi-Alopecuretum pratensis, Ventenato dubii-Trifolietum pallidi, Ranunculo strigulosi-Alopecuretum pratensis, and Ornithogalo pyramidale-Trifolietum pallidi. The main threats to these communities are natural succession and reforestation, intensive agriculture, and changes of hydrological regime; therefore, mowing, extensive agriculture, and maintenance of favorable hydrological regime are crucial for maintaining these highly diverse plant communities.

Charophytes that are present in all continents with the exception of Antarctica are a group of algae that colonize fresh and brackish water bodies, where they can form large stands. The establishment of these stands is affected by nutrient availability, water transparency, wave disturbances, water level fluctuations, substrate type, and water depth [13]. Charophytes are bioindicators of ecological status in lakes and rivers, while their oospores in the sediment can be used for the reconstruction of trophic status or salinity of such ecosystems in the past. Stragauskaite et al. [14] studied the distribution and seasonal patterns of a charophyte oospore bank and its relationship with abiotic factors and charophyte stands distribution in the largest lagoon in the Baltic Sea. The study revealed that the distance of oospores from the charophyte stands, salinity, and bottom slope were environmental factors defining the distribution of charophyte fructifications. In addition, wave exposure was also an important factor affecting oospore occurrence. The future increase in storm frequency and consequently increased wave action and turbidity may thus cause changes in spatial patterns of charophyte communities.

The contribution of Gaberščik et al. [15] analyzes the long-term response of cosmopolitan species Phragmites australis to extreme water level fluctuations. The study was performed in intermittent wetland Lake Cerknica, which is located at the bottom of the Cerkniško polje depression. This intermittence is a consequence of the karst features of the area, such as a high precipitation range and carbonate bedrock, which is mainly limestone. As an outstanding system with extreme water level fluctuations, resulting in long aquatic and relatively short dry phases, the lake is also listed as a Ramsar site. The lake area is colonized by extensive reed stands that thrive in different habitat types. P. australis is a highly productive species; however, unfavorable environmental conditions may easily reduce this potential. The authors compared common reed production parameters in plants from riparian and lake (littoral) stands within 13 years. The growth and assimilate allocation parameters in the lake reed were related to water levels for June and July, while temperatures were important at the beginning of the growing season in May. In the case of riparian reed, the water levels and temperatures out of the vegetation season appeared to be more important. The authors concluded that habitats with permanent water presence are more suitable for reeds than those with fluctuating water, which occasionally dry out. However, such an extreme hydrological regime that is becoming a reality not only in wetlands but also in other water bodies colonized by common reed can result in positive and negative feedback loops that may affect reed production. This study is an important contribution to the understanding of the changes in the structure and function of reed-dominated wetlands in the future.

Worldwide, lakes show a significant decrease in aquatic vegetation (cca. 65\%) [16] presumably due to water level changes, nutrient input, and global climate change. Water level fluctuations in lakes may be due to natural causes or due to human interventions. To build a basis of sustainable lake restoration and management, Tan et al. [17] examined 
the relationship between aquatic vegetation coverage and water levels in an artificially regulated shallow lake Longgan Lake located in the middle section of the Yangtze River. Based on long-term data that were obtained using medium-resolution Landsat satellite imagery, they aimed to understand the long-term dynamic of aquatic vegetation. Aquatic vegetation distribution showed a significant negative relationship with a water level. As water depth is the most important factor for aquatic plant growth and development, the expansion and retreat of aquatic vegetation was also related to the lake-bottom topography. The aquatic vegetation was negatively affected by high spring and summer water level. In the seasons with extremely high precipitation rates, the area colonized by aquatic vegetation was low. The authors concluded that the optimal water depths for successful aquatic vegetation growth are $1 \mathrm{~m}$ in spring and $3 \mathrm{~m}$ in summer, respectively.

\section{Conclusions}

A hydrological regime is one of the main factors shaping vegetation patterns across a wide range of scales. A hydrological gradient and a fluctuating water level present major driving forces, which determine the distribution of different plant communities as well as plant species composition within them. This was evidenced in various aquatic ecosystems, such as wet-meadows [12], marshes [4], intermittent lake [15], flood-forests [11], ponds [10], lakes [3,17], or rivers [6]. Waterlogged or flooded soil can become an inhospitable environment, which excludes the majority of species, while in the remaining species, it triggers the expression of various traits and mechanisms that enable survival despite oxygen shortage in the root zone. In addition, moving water masses as waves or current present a physical factor preventing successful colonization of certain communities $[7,14]$. Thus, when various factors shaping the plant communities are assessed [6] according to their importance, a hydrological regime often overrides all other environmental factors, also altering the pattern of regionality, which is generally accepted in biogeography [7].

This Special Issue contributed significantly to the understanding of the responses of plant species and communities that are favorized by specific hydrological regimes. Nowadays, these plant species and communities seem to be very vulnerable and threatened, since favorable hydrological conditions are changing due to anthropogenic alterations as well as by climate change that additionally endanger their long-term survival.

Author Contributions: Writing—original draft preparation, A.G. and I.Z.; writing-review and editing, I.Z. and A.G. All authors have read and agreed to the published version of the manuscript.

Funding: This research received no direct external funding.

Institutional Review Board Statement: Not applicable.

Informed Consent Statement: Not applicable.

Acknowledgments: Thanks to the authors who contributed their articles to this Special Issue as well as to the editors of the journal Water. A special thank goes to the anonymous reviewers, who provided their comments and suggestions and helped to improve the quality of the articles.

Conflicts of Interest: The authors declare no conflict of interest.

\section{References}

1. Keddy, P.A. Wetland Ecology: Principles and Conservation, 2nd ed.; Cambridge University Press: Cambridge, UK, 2010.

2. Boulton, A.J.; Brock, M.A. Australian Freshwater Ecology: Processes and Management; Gleneagles Publishing: Adelaide, Australia, 1999; p. 118.

3. Šumberová, K.; Vild, O.; Ducháček, M.; Fabšičová, M.; Potužák, J.; Fránková, M. Drivers of macrophyte and diatom diversity in a shallow hypertrophic lake. Water 2021, 13, 1569. [CrossRef]

4. Kúr, P.; Píšová, S.; Tremetsberger, K.; Dřevojan, P.; Kącki, Z.; Böckelmann, J.; Bernhardt, K.-G.; Hroudová, Z.; Mesterházy, A.; Šumberová, K. Ecology and genetics of cyperus fuscus in central Europe-A model for ephemeral wetland plant research and conservation. Water 2021, 13, 1277. [CrossRef]

5. S Šilc, U.; Vreš, B.; Čelik, T.; Gregorič, M. Biodiversity of Slovenia. In The Geography of Slovenia; Perko, D., Ciglič, R., Zorn, M., Eds.; Springer Nature Switzerland AG: Cham, Switzerland, 2020; pp. 109-124. 
6. Zelnik, I.; Kuhar, U.; Holcar, M.; Germ, M.; Gaberščik, A. Distribution of vascular plant communities in Slovenian watercourses. Water 2021, 13, 1071. [CrossRef]

7. Janauer, G.; Exler, N.; Anačkov, G.; Barta, V.; Berczik, Á.; Boža, P.; Dinka, M.; Georgiev, V.; Germ, M.; Holcar, M.; et al. Distribution of the macrophyte communities in the danube reflects river serial discontinuity. Water 2021, 13, 918. [CrossRef]

8. Vannote, R.L.; Minshall, G.W.; Cummins, K.W.; Sedell, J.R.; Cushing, C.E. The river continuum concept. Can. J. Fish. Aquat. Sci. 1980, 37, 130-137. [CrossRef]

9. Illies, J.; Botosaneanu, L. Problèmes et méthodes de la classification et de la zonation écologique des eaux courantes, considerées surtout du point de vue faunistique. SIL Commun. 1953-1996 1963, 12, 1-57. [CrossRef]

10. Pätzig, M.; Düker, E. Dynamic of dominant plant communities in Kettle Holes (Northeast Germany) during a five-year period of extreme weather conditions. Water 2021, 13, 688. [CrossRef]

11. Shupe, H.A.; Hartmann, T.; Scholz, M.; Jensen, K.; Ludewig, K. Carbon stocks of hardwood floodplain forests along the Middle Elbe: The influence of forest age, structure, species, and hydrological conditions. Water 2021, 13, 670. [CrossRef]

12. Čarni, A.; Ćuk, M.; Zelnik, I.; Franjić, J.; Igić, R.; Ilić, M.; Krstonošić, D.; Vukov, D.; Škvorc, Ž. Wet meadow plant communities of the alliance Trifolion pallidi on the southeastern margin of the Pannonian Plain. Water 2021, 13, 381. [CrossRef]

13. Schneider, S.C.; García, A.; Martín-Closas, C.; Chivas, A.R. The role of charophytes (Charales) in past and present environments: An overview. Aquat. Bot. 2015, 120, 2-6. [CrossRef]

14. Stragauskaite, V.; Bučas, M.; Martin, G. Distribution of charophyte oospores in the curonian lagoon and their relationship to environmental forcing. Water 2021, 13, 117. [CrossRef]

15. Gaberščik, A.; Grašič, M.; Abram, D.; Zelnik, I. Water level fluctuations and air temperatures affect common reed habitus and productivity in an intermittent wetland ecosystem. Water 2020, 12, 2806. [CrossRef]

16. Zhang, Y.; Jeppesen, E.; Liu, X.; Qin, B.; Shi, K.; Zhou, Y.; Thomaz, S.M.; Deng, J. Global loss of aquatic vegetation in lakes. Earth-Sci. Rev. 2017, 173, 259-265. [CrossRef]

17. Tan, W.; Xing, J.; Yang, S.; Yu, G.; Sun, P.; Jiang, Y. Long term aquatic vegetation dynamics in Longgan Lake using landsat time series and their responses to water level fluctuation. Water 2020, 12, 2178. [CrossRef] 